\title{
Long-lasting Modulation of Glutamatergic Transmission in VTA Dopamine Neurons after a Single Dose of Benzodiazepine Agonists
}

\author{
Anne E Heikkinen', Tommi P Möykkynen' and Esa R Korpi*,' \\ IInstitute of Biomedicine, Pharmacology, University of Helsinki, Helsinki, Finland
}

Initial effects of drugs of abuse seem to converge on the mesolimbic dopamine pathway originating from the ventral tegmental area (VTA). Even after a single dose, many drugs of abuse are able to modulate the glutamatergic transmission activating the VTA dopamine neurons, which may represent a critical early stage in the development of addiction. Ligands acting on the benzodiazepine site of the inhibitory $\gamma$-aminobutyric acid type $A\left(G A B A_{A}\right)$ receptors are known to be rewarding in animal models and have abuse liability in humans, but notably little evidence exists on the involvement of the mesolimbic dopamine system in their effects. Here we report that single in vivo doses of benzodiazepine-site agonists, similar to morphine and ethanol, induce a modulation in the glutamatergic transmission of VTA dopamine neurons. This is seen $24 \mathrm{~h}$ later as an increase in the ratio between $\alpha$-amino-3-hydroxy-5-methyl-4isoxazolepropionic acid (AMPA) and N-methyl-D-aspartate (NMDA) receptor-mediated excitatory currents using whole-cell patch-clamp configuration in mouse VTA slices. The effect was due to increased frequency of spontaneous miniature AMPA receptor-mediated currents. It lasted at least 3 days after the injection of diazepam, and was prevented by coadministration of the benzodiazepine-site antagonist flumazenil or the NMDA receptor antagonist dizocilpine. A single injection of the GABA $A_{A}$ receptor $\alpha \mid$ subunit-preferring benzodiazepine-site ligand zolpidem also produced an increase in the AMPA/NMDA ratio in VTA dopamine neurons. These findings suggest a role for the mesolimbic dopamine system in the initial actions of and on neuronal adaptation to benzodiazepines. Neuropsychopharmacology (2009) 34, 290-298; doi:I 0.1038/npp.2008.89; published online 18 June 2008

Keywords: midbrain dopamine neurons; diazepam; zolpidem; benzodiazepine dependence; AMPA receptors; plasticity

\section{INTRODUCTION}

Benzodiazepine-site ligands (BZs) of the $\gamma$-aminobutyric acid type $\mathrm{A}\left(\mathrm{GABA}_{\mathrm{A}}\right)$ receptors, such as diazepam $(\mathrm{DZ})$ and zolpidem (ZOL), are commonly used to treat anxiety disorders and sleep disturbances, respectively. Although $\mathrm{BZs}$ are clinically effective, they have, unfortunately, reinforcing properties and abuse potential in both humans and animal models of addiction (Griffiths and Weerts, 1997), with a subset of users developing drug dependence, tolerance, and withdrawal syndrome (Petursson, 1994; Ashton, 2005).

Neural mechanisms underlying BZ tolerance and withdrawal symptoms associated with $\mathrm{BZ}$ dependence are not well known. Although the $\mathrm{GABA}_{\mathrm{A}}$ receptors are the direct targets of $\mathrm{BZ}$ ligands, studies focusing on alterations in GABAergic systems have not been able to present a clear consensus. Actually, it has been suggested that the

*Correspondence: Professor ER Korpi, Institute of Biomedicine, Pharmacology, University of Helsinki, POB 63, Haartmaninkatu 8, Fl-000 |4, Finland, Tel: + 3589 19| 25330, Fax: + 3589 19925364, E-mail: esa.korpi@helsinki.fi

Received 4 January 2008; revised 4 April 2008; accepted 19 May 2008 excitatory glutamatergic transmission is enhanced as a compensatory mechanism to chronic enhancement of the inhibitory GABAergic transmission by BZs (Stephens, 1995). Regulation of the glutamatergic systems by chronic BZ treatments is well established in some limbic and cortical areas (Izzo et al, 2001; Van Sickle et al, 2002; Allison and Pratt, 2006). Particularly, in rats withdrawing from chronic flurazepam treatment, neurotransmission mediated by $\alpha$-amino-3-hydroxy-5-methyl-4-isoxazolepropionic acid (AMPA)-type glutamate receptors in the hippocampal CA1 pyramidal neurons is enhanced due to increased membrane incorporation of GluR1 subunitcontaining AMPA receptors (Song et al, 2007). This enhanced glutamatergic transmission in the hippocampus is also associated with anxiety-like behavior (Xiang and Tietz, 2007). Furthermore, it has been shown that the development of $\mathrm{DZ}$ tolerance and dependence can be prevented by concurrent treatment with the $N$-methyl-Daspartate (NMDA) receptor antagonist dizocilpine (Steppuhn and Turski, 1993). All these findings propose a role for various glutamatergic receptor systems of the brain in $\mathrm{BZ}$ tolerance and withdrawal. However, the neural basis for BZ reinforcement has not been clarified by these studies. 
Regardless of their specific target molecules and general behavioral manifestations, the effects of drugs of abuse seem to converge at the mesolimbic dopamine (DA) pathway originating from the ventral tegmental area (VTA). This is seen, eg in drug-induced DA release in the nucleus accumbens, the target area of the pathway (Di Chiara and Imperato, 1988; Koob, 1992). The DA pathways are important in reinforcement and reward processing (Wise, 1996; Schultz, 1998).

The role of mesolimbic DA projections in the effects of BZs is still unclear. Systemically administered BZs decrease extracellular DA in the nucleus accumbens (Finlay et al, 1992). On the other hand, blocking DA receptors with the antipsychotic drug haloperidol or lesioning the nucleus accumbens prevents DZ-induced conditioned place preference (Spyraki and Fibiger, 1988). In addition, intravenously administered DZ increases the firing of VTA DA neurons (O'Brien and White, 1987), which can be explained by the finding that intravenously or microiontophoretically administered BZs inhibit GABAergic interneurons in the VTA leading to disinhibition of VTA DA neurons (O'Brien and White, 1987). The $\gamma 2$ subunit of $\mathrm{GABA}_{\mathrm{A}}$ receptor is obligatory for $\mathrm{BZ}$ sensitivity (Pritchett et al, 1989). This subunit is expressed in the VTA both in DA and non-DA cells (Korpi et al, 2002; Okada et al, 2004), making it possible for all VTA neurons to be direct targets of BZs.

Glutamatergic synapses on VTA DA neurons can undergo several forms of plasticity, such as long-term potentiation (LTP) and depression (Bonci and Malenka, 1999). Longlasting alterations in synaptic strength are thought to underlie memory formation and learning (Huang et al, 1996). It has been suggested that the process of addiction is founded on a very persistent, but maladaptive, neural plasticity that resembles the plasticity associated with natural reward learning and memory (Kauer, 2004; Jones and Bonci, 2005). This may take place particularly in the mesolimbic DA system (Fitzgerald et al, 1996; Thomas et al, 2001). Importantly, even single in vivo injections of several different drugs of abuse induce a modulation in the excitatory synapses at VTA DA neurons seen in vitro by electrophysiological methods (Ungless et al, 2001; Saal et al, 2003). The quick and persistent drug-induced plasticity may be a critical early stage in a chain of molecular/cellular events that could facilitate development of addiction. Because of the unclear and controversial nature of the mesolimbic DA system in BZ dependence, we have studied the effects of single in vivo doses of the classical BZ agonist DZ and the novel subtype-preferring BZ-site agonist ZOL on glutamatergic transmission in VTA DA neurons, and found that these drugs induce long-lasting alterations in the currents mediated by AMPA-type glutamate receptors.

\section{MATERIALS AND METHODS}

\section{Animals and Drug Injections}

C57BL/6NHsd female and male mice were purchased from Harlan BV (Horst, the Netherlands) and maintained for up to three generations at our facility. We used the offspring aged between 21 and 29 days for all experiments. Animals were weaned 1 or 2 days before the drug injections. They were group-housed in standard cages with woodchips covering the bottoms, in a ventilated Uniprotect cabinet (Ehret, Emmendingen, Germany) under $12 \mathrm{~h}$ light/dark conditions (lights on at 6 a.m.) with food (Harlan Teklad, Oxon, UK) and water available ad libitum. Mice were injected intraperitoneally between 8 and 9 a.m., 24-30 h before preparing VTA slices. The drug doses used were: DZ (5 or $20 \mathrm{mg} / \mathrm{kg}$ ), morphine $(10 \mathrm{mg} / \mathrm{kg})$, ethanol $(2 \mathrm{~g} / \mathrm{kg})$, ZOL (5 mg/kg), flumazenil (FLU; 10 and $15 \mathrm{mg} / \mathrm{kg}$ ), and dizocilpine (MK-801; $0.1 \mathrm{mg} / \mathrm{kg})$. FLU was injected at two time points: first, the dose of $15 \mathrm{mg} / \mathrm{kg} 10 \mathrm{~min}$ before $\mathrm{DZ}$ injection and second, the dose of $10 \mathrm{mg} / \mathrm{kg} 30 \mathrm{~min}$ after DZ, a schedule that prevented any visible sedating effects of DZ. Animals injected with vehicle (saline or ClinOleic $20 \%$ emulsion) were used as controls throughout the experiments. Drugs were injected at a volume of $100 \mu \mathrm{l}$ per $10 \mathrm{~g}$ of body weight. All experiments were approved by the Helsinki University Animal Care Committee.

\section{Spontaneous Locomotor Activity}

To measure spontaneous locomotor activity after DZ treatment, mice were injected with $\mathrm{DZ}(5 \mathrm{mg} / \mathrm{kg}$, i.p.) or vehicle $24 \mathrm{~h}$ before testing the activity. Mice were adapted to the experimental room, in their home cages, for $1 \mathrm{~h}$ before testing. Locomotor activity was measured for $30 \mathrm{~min}$ in Makrolon cages $(42 \times 26 \times 20 \mathrm{~cm}$; Tecniplast, Buguggiate, Italy), in which the distance moved (in $\mathrm{cm}$ ) by the mouse was registered by Ethovision Color-Pro 3.0 video-tracking software (Noldus Information Technology, Wageningen, The Netherlands).

\section{Slice Preparation}

Animals were decapitated $24-30 \mathrm{~h}$ after the in vivo injections of the drugs (or $24 \mathrm{~h}$ to 5 days after DZ injections, when determining the time course of the DZ effect). The brains were rapidly removed and rinsed in ice-cold carbogen-bubbled cutting solution (containing in mM: 60 $\mathrm{NaCl}, 2 \mathrm{KCl}, 8 \mathrm{MgCl}_{2}, 0.3 \mathrm{CaCl}_{2}, 30 \mathrm{NaHCO}_{3}, 1.25 \mathrm{NaH}_{2} \mathrm{PO}_{4}$, 140 sucrose, and $10 \mathrm{D}$-glucose). A block of tissue containing the midbrain was sliced horizontally into $225-\mu \mathrm{m}$-thick VTA-containing slices using a vibratome (vibratome 1000 Plus, Vibratome, St Louis, MO, USA). The slices were then let to recover at $+32^{\circ} \mathrm{C}$ in carbogen-bubbled artificial cerebrospinal fluid (ACSF, in $\mathrm{mM}: 126 \mathrm{NaCl}, 1.6 \mathrm{KCl}$, $1.2 \mathrm{NaH}_{2} \mathrm{PO}_{4}, 1.2 \mathrm{MgCl}_{2}, 2.5 \mathrm{CaCl}_{2}, 18 \mathrm{NaHCO}_{3}$, and 11 $\mathrm{D}$-glucose) for at least $1 \mathrm{~h}$ before recordings.

\section{Electrophysiological Recordings}

The recordings were made in carbogen-bubbled ACSF that was perfused over the slice in a recording chamber (RCP6T; Dagan, Minneapolis, MN, USA) at a rate of $2 \mathrm{ml} / \mathrm{min}$. Cells were visualized using an upright microscope (Olympus BX51WI, Hamburg, Germany) with infrared illumination and a digital camera (Hamamatsu C8484, Hamamatsu City, Japan). Whole-cell voltage-clamp recordings were conducted with an Axopatch 200B patch-clamp amplifier and digitized with a Digidata 1322A analog-to-digital converter and pClamp 9.0 software (Axon Instruments, 
Union City, CA, USA). The recordings were low-pass filtered at $2 \mathrm{kHz}$ and digitized at $20 \mathrm{kHz}$. Electrodes had a resistance of 3-5 $\mathrm{M} \Omega$ when filled with internal solution containing (in $\mathrm{mM}$ ): 130 cesium methanesulfonate, 10 HEPES, 0.5 EGTA, $8 \mathrm{NaCl}, 5$ QX314, 4 MgATP, 0.3 MgGTP, and 10 BAPTA ( $\mathrm{pH}$ adjusted to 7.2-7.25 with $\mathrm{CsOH}$, osmolarity $278 \pm 5 \mathrm{mOsm}$ ). The series and input resistances were monitored throughout the experiments. Series resistance of $<20 \mathrm{M} \Omega$ was accepted, and if it changed more than $20 \%$ during the recording, the cell was discarded from the analysis.

\section{Identification of Dopaminergic Neurons in VTA}

In horizontal midbrain slices, the VTA was recognized as the area medial to the substantia nigra compacta and medial to the terminal nucleus of the accessory optic tract. A neuron was identified dopaminergic if a clear hyperpolarization-activated cation current $\left(I_{\mathrm{h}}\right.$ current) emerged after hyperpolarizing the neuron from -70 to $-130 \mathrm{mV}$ in $10 \mathrm{mV}$ steps immediately after break-in. $I_{\mathrm{h}}$ current is a good marker for dopaminergic neurons in the mouse midbrain, being present in more than $90 \%$ of them (Cameron et al, 1997; Neuhoff et al, 2002; Wanat et al, 2008). Recent findings in rats, on the other hand, have questioned whether its presence could unequivocally identify DA cells (Margolis et al, 2006). However, in previous studies (Ungless et al, 2001; Saal et al, 2003; Faleiro et al, 2004; Wanat et al, 2008) as well as in the present study, this criterion was sufficient to obtain clear differences between the cells from control and experimental animals.

\section{AMPA/NMDA Ratio}

The whole-cell ratio for the AMPA and NMDA receptormediated currents (AMPA/NMDA ratio) was calculated to assess the synaptic strength of glutamatergic synapses in VTA DA neurons (Ungless et al, 2001; Saal et al, 2003). This measurement offers the advantage that it is independent of the number of synapses activated. In brief, excitatory postsynaptic currents (EPSCs) were evoked by electrical pulses delivered at $0.1 \mathrm{~Hz}$ frequency by a stimulator ( $\mathrm{S}-900$; Dagan) through a bipolar stimulus electrode placed on the slice $100-300 \mu \mathrm{m}$ rostral to the recording site to stimulate the glutamatergic afferents to VTA. Stimulus intensity was set at the lowest level that evoked stable EPSCs (usually about $100 \mathrm{pA})$ with no failures. Picrotoxin $(100 \mu \mathrm{M})$ was added to block the $\mathrm{GABA}_{\mathrm{A}}$ receptor-mediated inhibitory currents. The recordings were made in voltage-clamp configuration at $+40 \mathrm{mV}$ as described earlier (Ungless et al, 2001). After recording stable baseline EPSCs for 5-10 min, $50 \mu \mathrm{M}$ D-(-)-2-amino-5-phosphonopentanoic acid (D-AP5) was added to perfusion to prevent the NMDA receptor-mediated currents. After $5 \mathrm{~min}$ perfusion with $\mathrm{D}-\mathrm{AP} 5$, the remaining AMPA receptor-mediated current was recorded for 5-10 min. To calculate the AMPA/NMDA ratio the average AMPA current (the average response in the presence of D-AP5) was subtracted from the average baseline EPSC, revealing the average NMDA current. The AMPA/NMDA ratio was calculated from the peak amplitude of the currents.

\section{Miniature Excitatory Postsynaptic Currents and Paired-Pulse Ratios}

Spontaneous AMPA receptor-mediated miniature excitatory postsynaptic currents (mEPSCs) were recorded in VTA DA neurons clamped at $-70 \mathrm{mV}$, in the presence of $100 \mu \mathrm{M}$ picrotoxin, $1 \mu \mathrm{M}$ tetrodotoxin (TTX), and $50 \mu \mathrm{M}$ D-AP5, at $+32^{\circ} \mathrm{C}$. Spontaneous mEPSCs were analyzed with Mini Analysis program software (Synaptosoft Inc., Decatur, GA, USA). Briefly, mEPSCs were screened by using an amplitude threshold of $8 \mathrm{pA}$, and based upon the shape of the event (rise $<1.5 \mathrm{~ms}$ and decay $<3.5 \mathrm{~ms}$ ), they were visually either accepted or rejected by an examiner blind to the experimental conditions. Electrical noise was typically around $3 \mathrm{pA}$ in amplitude. For each neuron the mEPSCs were recorded for a $5 \mathrm{~min}$ period.

Paired-pulse ratios were recorded in VTA DA neurons at $-70 \mathrm{mV}$ in the presence of $100 \mu \mathrm{M}$ picrotoxin and $50 \mu \mathrm{M}$ D-AP5. The excitatory afferents were stimulated electrically with paired pulses to evoke two responses with short time intervals: 20, 50 and $100 \mathrm{~ms}$ at $0.1 \mathrm{~Hz}$. The paired-pulse ratio was calculated between the peak amplitudes of the second and the first evoked excitatory current.

\section{Statistical Analyses}

Only two or three VTA slices per animal were obtained and only one recording per slice was made. The recordings from the same animal were averaged out, and this average was used in the analysis. All values are expressed as means \pm SEM. Statistical significance was assessed with two-tailed $t$-test, or one-way ANOVA with Tukey's or Dunnett's posttest using Prism 4.0 software (GraphPad Software, San Diego, CA, USA). Statistical significance was set at $p<0.05$.

\section{Drugs}

Diazepam (Stesolid Novum, Yliopiston Apteekki, Helsinki, Finland) was suspended in ClinOleic 20\% emulsion (Baxter Oy, Helsinki, Finland). Morphine-HCl (Yliopiston Apteek$\mathrm{ki}$ ) and dizocilpine maleate (MK-801; Tocris Bioscience, Bristol, UK) were diluted with saline. Ethanol (Altia Oyj, Rajamäki, Finland) was mixed with saline $(10 \% \mathrm{w} / \mathrm{v})$. ZOL tartrate (Stilnoct, Yliopiston Apteekki) was dissolved with saline. FLU (Sigma-Aldrich Finland Oy, Helsinki, Finland) was dissolved with Tween 80 and diluted with 1\% Tween 80 in saline. Stock solutions of picrotoxin, TTX, and D-AP5 (Tocris Bioscience) were diluted with ACSF, and added to perfusion medium when needed.

\section{RESULTS}

\section{One In Vivo Dose of Diazepam Leads to Increased AMPA/NMDA Ratio of VTA DA Neurons}

In agreement with Saal et al (2003), we found that single doses of morphine and ethanol led to a significant increase (morphine, $p<0.01$; ethanol, $p<0.001$ ) in the AMPA/ NMDA ratio measured from VTA DA neurons $24 \mathrm{~h}$ after the drug injection (Figure 1). We also found that a single injection of $\mathrm{DZ}$ at a dose of 5 or $20 \mathrm{mg} / \mathrm{kg}$, i.p., significantly 


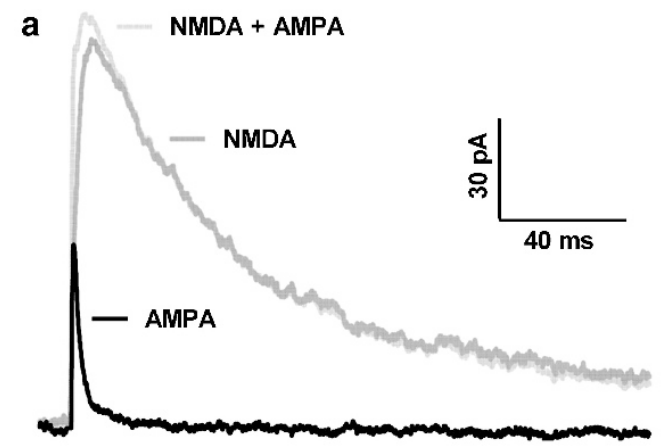

b

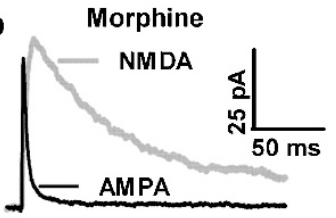

DZ5
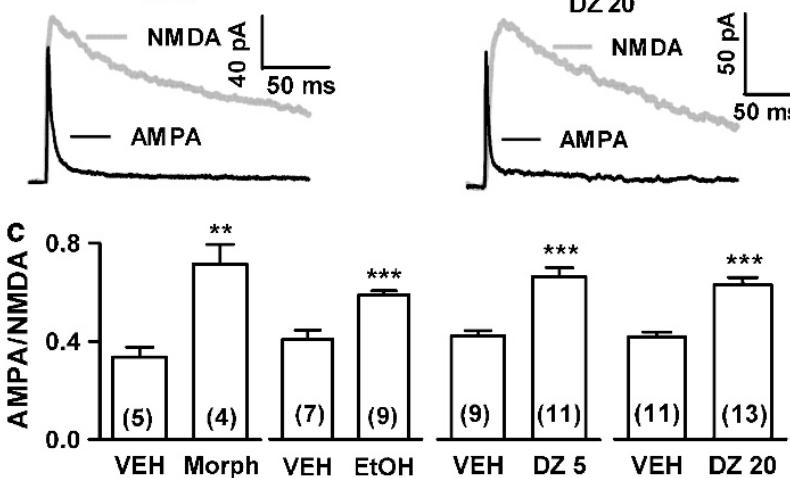

Figure I Modulation of $\alpha$-amino-3-hydroxy-5-methyl-4-isoxazolepropionic acid/N-methyl-D-aspartate (AMPA/NMDA) current ratios of ventral tegmental area (VTA) dopamine (DA) neurons measured ex vivo $24 \mathrm{~h}$ after single doses of drugs of abuse. (a) Example traces showing AMPA and NMDA components after vehicle administration. (b) Representative AMPA and NMDA receptor-mediated current traces recorded after single doses of morphine, ethanol (EtOH) and two doses of diazepam (DZ). (c) Bars ( \pm SEM, the number of animals tested in parentheses) showing the average AMPA/NMDA ratio after one in vivo injection of morphine hydrochloride $(10 \mathrm{mg} / \mathrm{kg}), \mathrm{EtOH}(2 \mathrm{~g} / \mathrm{kg})$, and DZ (5 or $20 \mathrm{mg} / \mathrm{kg}$ ). All drug doses increased the AMPA/NMDA ratios compared to the corresponding vehicle administration. ${ }^{*} p<0.01$ and $* * * * 00.001$ ( $t$-test).

$(p<0.001)$ increased the AMPA/NMDA ratio in VTA DA neurons (Figure 1). The effect was similar at both doses, and also very similar to that produced by morphine and ethanol. Behaviorally, the mice showed heavy sedation (loss of locomotor activity) within a few $\mathrm{min}$ after the DZ $(5 \mathrm{mg} / \mathrm{kg}$, i.p.) injection, and they started to recover around $60 \mathrm{~min}$ afterward, with no visible sedation anymore after $2-3 \mathrm{~h}$ (based on visual observations of the mouse activity induced by moving the home cage and the lid).

In another group of mice, we determined spontaneous locomotor activity in a novel environment $24 \mathrm{~h}$ after the administration of $5 \mathrm{mg} / \mathrm{kg} \mathrm{DZ}$ or vehicle. The distance traveled by the mice in 30 min was $5178 \pm 135$ (mean \pm SEM, $n=5)$ and $5464 \pm 230 \mathrm{~cm}(n=7)$ for the vehicle and $\mathrm{DZ}$ groups, respectively $(p>0.05)$.
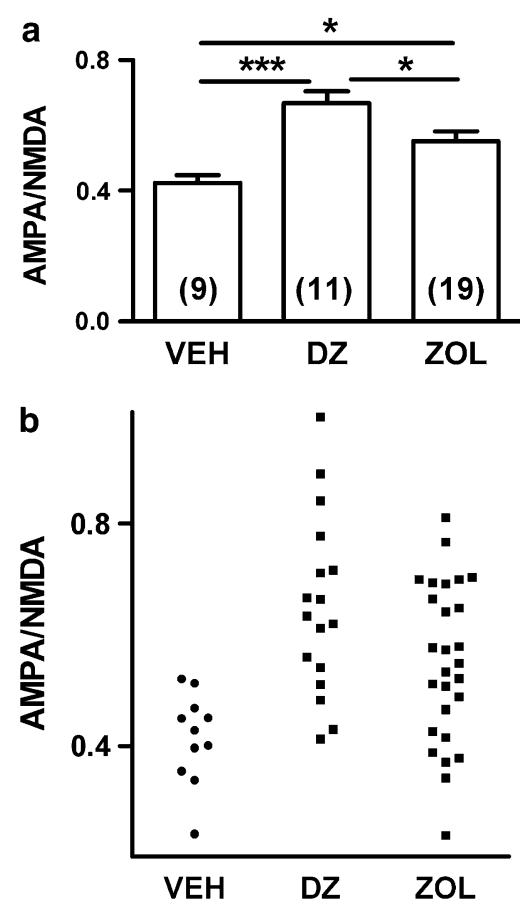

Figure 2 The average $\alpha$-amino-3-hydroxy-5-methyl-4-isoxazolepropionic acid/N-methyl-D-aspartate (AMPA/NMDA) current ratios ( \pm SEM, the number of animals tested in parentheses) in the ventral tegmental area (VTA) dopamine (DA) neurons $24 \mathrm{~h}$ after diazepam (DZ, $5 \mathrm{mg} / \mathrm{kg}$ ) and zolpidem tartrate $(Z O L, 5 \mathrm{mg} / \mathrm{kg})$. (a) The drug treatment increased the AMPA/NMDA ratio $(F(2,38)=11.15, p<0.0002)$, but $Z O L$ had a smaller effect. $* p<0.05$, ***** $p<0.00$ I (Tukey's test). (b) Cluster plot of AMPA/ NMDA ratios for individual neurons after vehicle, DZ and ZOL treatments. From several animals, more than one neuron was recorded, each from a different midbrain slice. The data suggest that fewer neurons had altered glutamatergic transmission after ZOL as compared to DZ.

\section{Zolpidem Increases the AMPA/NMDA Ratio}

$\mathrm{GABA}_{\mathrm{A}}$ receptor $\mathrm{BZ}$ sites show pharmacologically significant heterogeneity (Lüddens et al, 1995). DZ shows relatively little selectivity in binding affinity between $\mathrm{GABA}_{\mathrm{A}}$ receptors containing $\alpha 1, \alpha 2, \alpha 3$, or $\alpha 5$ subunits, although its efficacy is slightly affected by the $\alpha$ variant (Ducic et al, 1993). The imidazopyridine ZOL, in contrast, is an $\alpha 1 \beta \gamma 2$ subtype-preferring BZ-site ligand, showing 10- to 20 -fold selectivity in affinity for $\mathrm{GABA}_{\mathrm{A}}$ receptors with $\alpha 1$ subunits over those with $\alpha 2$ or $\alpha 3$ subunits and even a greater selectivity difference for $\alpha 1$ over $\alpha 5$ subunitcontaining receptors (Faure-Halley et al, 1993; Sieghart, 1995). To assess the effects of ZOL, we injected the mice with ZOL at a dose of $5 \mathrm{mg} / \mathrm{kg} 24 \mathrm{~h}$ before recording the AMPA/NMDA ratio in the VTA DA neurons. At this dose, the effects of ZOL are specifically mediated by $\alpha 1$ subunitcontaining $\mathrm{GABA}_{\mathrm{A}}$ receptors (Crestani et al, 2000). ZOL was able to significantly $(p<0.05)$ increase the AMPA/NMDA ratio, but this effect seemed to be less pronounced than that of $5 \mathrm{mg} / \mathrm{kg} \mathrm{DZ}(p<0.05$; Figure 2).

\section{Modulation is Long Lasting and Dependent on NMDA Receptors}

We next studied the time course of the DZ-evoked increase in the AMPA/NMDA ratio of VTA DA neurons. The 

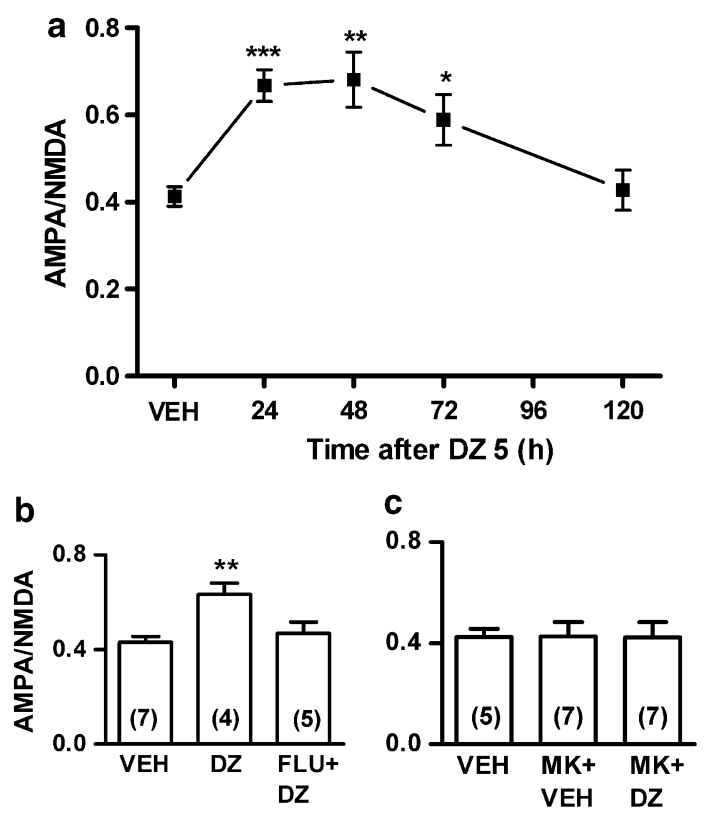

Figure 3 Time course and pharmacological manipulations of diazepam (DZ)-induced increase in the $\alpha$-amino-3-hydroxy-5-methyl-4-isoxazolepropionic acid/N-methyl-D-aspartate (AMPA/NMDA) current ratio of ventral tegmental area (VTA) dopamine (DA) neurons. (a) Points ( \pm SEM, $n=7-I I)$ showing the average AMPA/NMDA ratios $24 \mathrm{~h}$ to 5 days after a single injection of DZ $(5 \mathrm{mg} / \mathrm{kg})$. The ratio is increased for 3 days after the DZ $(F(4,40)=8.174, p<0.000 \mathrm{I})$ returning back to the baseline in 5 days. (b) The benzodiazepine receptor antagonist flumazenil (FLU) prevented the DZ-induced potentiation in the AMPA/NMDA ratio of VTA DA neurons, when injected $10 \mathrm{~min}$ before $(15 \mathrm{mg} / \mathrm{kg})$ and $30 \mathrm{~min}$ after $(10 \mathrm{mg} / \mathrm{kg})$ the DZ injection $(5 \mathrm{mg} / \mathrm{kg})$. (c) The NMDA receptor noncompetitive antagonist dizocilpine (MK-80, $0.1 \mathrm{mg} / \mathrm{kg}$ ) prevented the DZ-induced potentiation in the AMPA/NMDA ratio when co-injected with DZ (5 mg/kg). * $p<0.05, * * p<0.01$, and $* * * * p<0.00$ I (Dunnett's test).

phenomenon was still evident 3 days after the injection, but after 5 days the AMPA/NMDA ratio had returned back to the baseline (Figure 3a).

To ascertain that the effect of $\mathrm{DZ}$ is indeed mediated through the BZ-binding site of $\mathrm{GABA}_{\mathrm{A}}$ receptors, we injected the mice with the selective BZ-site antagonist FLU (Hunkeler et al, 1981) $10 \mathrm{~min}$ before $(15 \mathrm{mg} / \mathrm{kg}$ ) and $30 \mathrm{~min}$ after $(10 \mathrm{mg} / \mathrm{kg})$ the $\mathrm{DZ}(5 \mathrm{mg} / \mathrm{kg})$ injection. With this double-dosing schedule, FLU completely prevented the effect of DZ on the AMPA/NMDA ratio (Figure $3 \mathrm{~b}$ ). Interestingly, a single $15 \mathrm{mg} / \mathrm{kg}$ dose of FLU $10 \mathrm{~min}$ before the $5 \mathrm{mg} / \mathrm{kg} \mathrm{DZ}$ injection alone was not effective in preventing the DZ's effect on VTA DA neurons (the AMPA/NMDA ratios were $0.42 \pm 0.03(n=5), 0.62 \pm 0.05(n=4)$ and $0.57 \pm$ $0.09(n=5)$ for animals treated with vehicle, DZ and FLU + $\mathrm{DZ}$, respectively; $p>0.05$ for the difference between $\mathrm{DZ}$ and FLU + DZ).

Activation of NMDA receptors is a requirement for a single in vivo injection of cocaine to induce the potentiation of the AMPA/NMDA ratio in VTA DA neurons (Ungless et al, 2001). We found now that the NMDA receptor antagonist dizocilpine $(0.1 \mathrm{mg} / \mathrm{kg})$ itself had no effect on the ratio, but when it was co-injected with DZ $(5 \mathrm{mg} / \mathrm{kg})$, the DZ-induced increase in the ratio was fully prevented (Figure 3c).
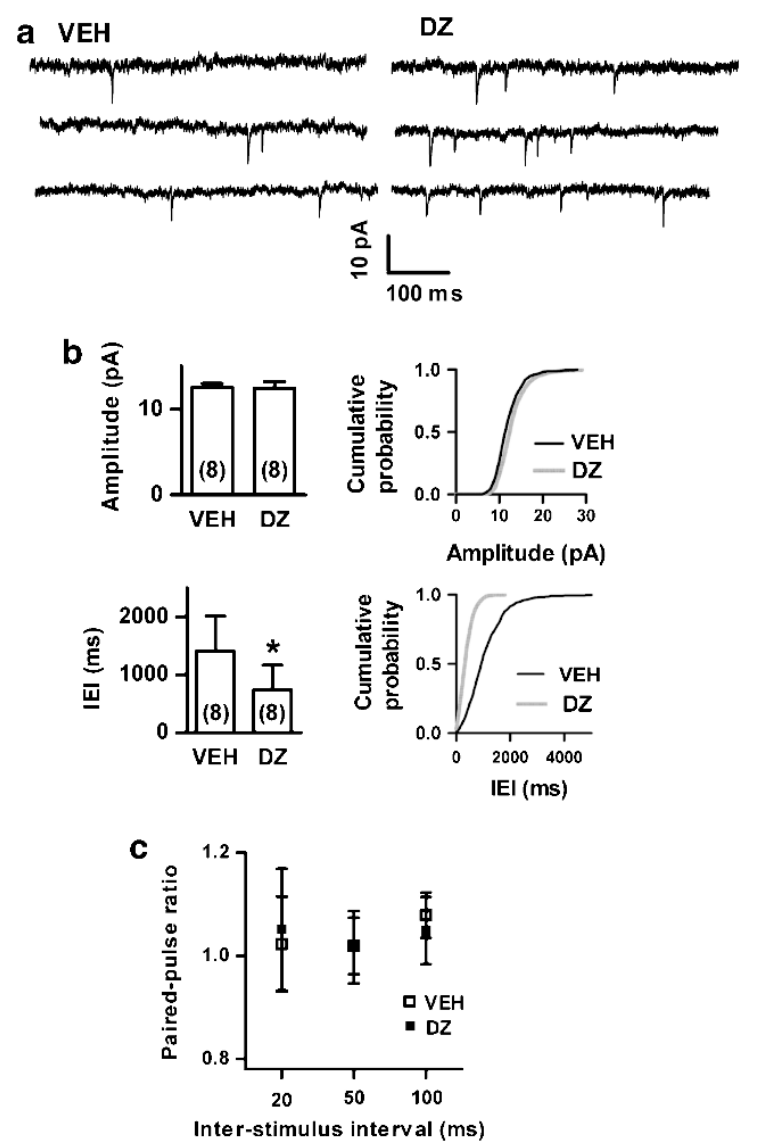

Figure 4 Spontaneous $\alpha$-amino-3-hydroxy-5-methyl-4-isoxazolepropionic acid (AMPA) receptor-mediated miniature excitatory postsynaptic currents (mEPSCs) and paired-pulse ratios in ventral tegmental area (VTA) dopamine (DA) neurons $24 \mathrm{~h}$ after a single injection of diazepam (DZ, $5 \mathrm{mg} / \mathrm{kg}$ ). (a) Representative traces recorded from DA neurons after vehicle or DZ treatments. (b) Means and cumulative probability plots for the amplitudes and interevent intervals (IEI) of mEPSCs recorded from the VTA DA neurons of vehicle- or DZ-treated animals. DZ had no effect on the mEPSC amplitudes $(p>0.05)$, but it decreased the IEI. $* p<0.05$ (t-test). (c) Paired-pulse ratios at various interstimulus intervals did not reveal any differences between groups $(p>0.05, t$-test). Data are means \pm SEM for eight animals in both groups for both experiments.

\section{Increased Frequency of AMPA Receptor mEPSCs in VTA DA Neurons after DZ Treatment}

To study the mechanism of potentiation of the AMPA/ NMDA ratio after DZ treatment, we recorded AMPA receptor-mediated spontaneous mEPSCs in VTA DA neurons $24 \mathrm{~h}$ after $\mathrm{DZ}(5 \mathrm{mg} / \mathrm{kg})$. The interevent interval (IEI) was shorter in the DZ-treated mice than in the vehicletreated mice $(p<0.05)$, indicating that $\mathrm{DZ}$ treatment had increased the frequency of mEPSCs (Figure 4a). The treatment did not change the amplitudes of the miniature currents.

To test whether a change in the probability of neurotransmitter release from glutamatergic nerve terminals was behind the increased frequency of AMPA events, we recorded AMPA receptor-mediated currents evoked by closely time-wise paired electrical pulses and calculated a so-called paired-pulse ratio in VTA DA neurons. The paired-pulse ratio is used to compare the probability of 
neurotransmitter release under control conditions and following drug treatments or experimental manipulations. An increase in release probability is typically associated with a decrease in paired-pulse ratio, and vice versa (Dobrunz and Stevens, 1997). However, DZ treatment of the mice did not change the paired-pulse ratios in VTA DA neurons (Figure 4b).

\section{DISCUSSION}

Different drugs of abuse can induce plasticity changes in the excitatory synapses of VTA DA neurons after a single dose of the drug. BZs are known to have abuse potential, but the role of mesolimbic DA system in BZ dependence and addiction has remained unclear. Here we show that similar to strongly addicting opioid morphine and alcohol, a single in vivo dose of the classical $\mathrm{GABA}_{\mathrm{A}}$ receptor-positive modulator BZ DZ induced a modulation in the glutamatergic transmission to VTA DA neurons, seen as an increase in the AMPA/NMDA current ratio.

The increase in the AMPA/NMDA ratio after $D Z$ was a relatively long-lasting modulation of synaptic transmission, being detectable at least for 3 days after the injection. On the basis of the literature, we can estimate that DZ at the dose of $5 \mathrm{mg} / \mathrm{kg}$ will be quickly metabolized to its active metabolites $\mathrm{N}$-desmethyldiazepam and oxazepam in mice, and that hardly any DZ should be present in the brain after $2 \mathrm{~h}$ (Coutinho et al, 1969; Greenblatt and Sethy, 1990). $\mathrm{N}$-desmethyldiazepam, which has roughly the same affinity to $\mathrm{BZ}$ receptors and the same hypnotic potency as DZ (but less anticonvulsant potency than diazepam) (Frey and Löscher, 1982; Gobbi et al, 1987; Klockowski and Levy, 1987), disappears from the brain at around $12 \mathrm{~h}$, whereas oxazepam has the longest elimination half-life of the active DZ metabolites and might be detectable at a very low level still at $24 \mathrm{~h}$ but unlikely to be detected at $48 \mathrm{~h}$ (Greenblatt and Sethy, 1990). However, oxazepam has clearly less hypnotic and anticonvulsant efficacy than DZ (Frey and Löscher, 1982; Klockowski and Levy, 1987). Thus, it is unlikely that the possible residual oxazepam is directly involved in the glutamate receptor modification $24-72 \mathrm{~h}$ after a single injection of DZ. This is also supported by the finding that $\mathrm{DZ}$ by potentiating the $\mathrm{GABA}_{\mathrm{A}}$ receptormediated inhibition in vitro prevents, and not facilitates, the LTP induction in VTA DA neurons of chronically cocaine-treated rats (Liu et al, 2005). Interestingly, repeated, but not a single, exposure to cocaine leads to a reduction in $\mathrm{GABA}_{\mathrm{A}}$ receptor-mediated inhibition in VTA DA neurons, which facilitates LTP induction (Liu et al, 2005; Pan et al, 2008). Although the $\mathrm{GABA}_{\mathrm{A}}$ receptor targets are present in the VTA in both DA and non-DA neurons (Korpi et al, 2002; Okada et al, 2004), at least in anesthetized rats BZs seem to act by inhibiting the non-DA neurons more strongly and thus leading to a disinhibition of the DA neurons of the area (O'Brien and White, 1987). Further experiments are warranted to ascertain the possible longlasting alterations in the $\mathrm{GABA}_{\mathrm{A}}$ receptor function as an after effect of a single dose or repeated doses of BZs, both in the DA and non-DA neurons of the VTA.

The effect of DZ on AMPA/NMDA ratio was mediated through the $\mathrm{BZ}$ site of $\mathrm{GABA}_{\mathrm{A}}$ receptor, as the selective antagonist FLU prevented it. This suggests that the acute enhancement of $\mathrm{GABA}_{\mathrm{A}}$ receptor-mediated transmission by $\mathrm{DZ}$ eventually leads to a modulation of the glutamatergic control of VTA DA neurons. However, we needed two high doses of FLU to block the modulation, indicating that the modulation happens in response to the initial strong action of DZ (and/or its metabolites) in the first few hours, which coincides with the clear behavioral effects. The elimination half-life of FLU in the rodent brain is short $(8-16 \mathrm{~min})$ and it is no longer detectable at $90 \mathrm{~min}$ (Lister et al, 1984; Mandema et al, 1991; Atack et al, 1999). This explains why one dose of FLU failed to prevent the emergence of the visible sedative effect of $\mathrm{DZ}$.

The $\mathrm{GABA}_{\mathrm{A}}$ receptor $\alpha 1$ subunit-preferring $\mathrm{BZ}$-site ligand ZOL has less abuse liability than DZ (Darcourt et al, 1999; Hajak et al, 2003; Griffiths and Johnson, 2005). Here we found that ZOL at the dose $(5 \mathrm{mg} / \mathrm{kg})$ that acts specifically via $\alpha 1$ subunit-containing receptors (Crestani et al, 2000) increased the AMPA/NMDA ratio in VTA DA neurons. Even if its effect seemed to be weaker than that of $5 \mathrm{mg} / \mathrm{kg}$ $\mathrm{DZ}$, we cannot directly compare the efficacy of the two drugs to induce a long-lasting neurobiological change when using only one dose. Although the affinities of ZOL and DZ for the $\alpha 1$ subunit-containing receptors might be similar or differ slightly (about twofold) in recombinant $\alpha 1 \beta 2 / 3 \gamma 2$ $\mathrm{GABA}_{\mathrm{A}}$ receptors (Wieland and Lüddens, 1994; Atack et al, $1999)$ and in $\alpha 1$ subunit-enriched regions of the rat brain (Arbilla et al, 1986; Benavides et al, 1988), the most important difference might be in the time course of action. ZOL is a short-acting hypnotic, with in vivo occupancy of the $\mathrm{GABA}_{\mathrm{A}}$ receptor $\mathrm{BZ}$ sites lasting only about $15-30 \mathrm{~min}$ after i.p. injection of $10 \mathrm{mg} / \mathrm{kg}$ in mice (Benavides et al, 1988). As discussed above with regard to FLU antagonism, the $\mathrm{BZ}$ effect may need to last longer than 15 min to induce the full and consistent modulation in the glutamate synapses of the VTA DA neurons. To reach that long an effect, higher ZOL doses would probably have been required. In any case, our data are in agreement with the results of self-administration of several subtype-selective BZ ligands by rhesus monkeys indicating that the activation of $\alpha 1$ subunit-containing $\mathrm{GABA}_{\mathrm{A}}$ receptors is sufficient for abuse potential of BZ-type drugs (Rowlett et al, 2005).

The increase in AMPA/NMDA ratio may happen as a result of an enhancement in AMPA receptor-mediated neurotransmission at existing excitatory synapses and/or emergence of newly formed synapses. We found here that $\mathrm{DZ}$ injection increased the frequency of spontaneous miniature AMPA currents in VTA DA neurons, although the amplitudes remained unaltered. This could be interpreted as a presynaptic alteration, suggesting that the transmitter release probability has changed. Depending on synapses and experimental techniques, BZs may directly or indirectly either enhance or reduce glutamate release (Schmid et al, 1999; Khan et al, 2000; Harte and O'Connor, 2004). However, we found no differences in paired-pulse ratios between the treatments, indicating that the release probability of glutamate in the excitatory synapses of VTA DA neurons after DZ remained unchanged.

The increased frequency of the miniature AMPA events without a change in the amplitude may result from a postsynaptic alteration. If $\mathrm{DZ}$ treatment induced formation of new glutamatergic synaptic contacts, increased AMPA receptor-mediated responses would ensue in the DA 
neurons. This idea is intriguingly supported by the recent finding of increased dendritic spine density in those VTA DA neurons that exhibited increased AMPA/NMDA ratio in rats after a single injection of cocaine in vivo (Sarti et al, 2007). In the hippocampus, it has been shown that the exocytosis of recycling endosomes containing AMPA receptors could be the mechanism behind new spine formation (Park et al, 2006) and this would nicely support the idea of enhancement of AMPA transmission in these neurons. Interestingly, the increase in the AMPA/NMDA ratio after DZ was prevented if the NMDA-receptor antagonist dizocilpine was co-injected with DZ, even though this drug has a relatively short half-life in rodents (elimination $t \frac{1}{2}$ for dizocilpine approximately $60-75 \mathrm{~min}$ in rats (Hucker et al, 1983)). Therefore, systemic DZ administration has to lead to activation of NMDA receptors, to enable the modulation of excitatory synapses of VTA DA neurons to occur during the $24 \mathrm{~h}$. In agreement, also after cocaine injection the activation of NMDA receptors is needed for the AMPA potentiation to develop in the VTA DA neurons (Ungless et al, 2001). Thus, the phenomenon we observed shows similarity to the classical model of synaptic plasticity, the NMDA-dependent LTP. It is set in motion by NMDA receptor activation and intracellular calcium signaling, leading to exocytosis of recycling AMPA receptors and recycling endosomes, finally resulting in increased synaptic strength and spine formation and growth (Lüscher et al, 2000; Park et al, 2006). Learning and long-lasting synaptic modifications are dependent on gene expression and protein synthesis (see for reviews Sutton and Schuman, 2006; McClung and Nestler, 2008), whereas many functional synaptic changes such as the rapid entry and exit of the AMPA receptors to/from cell surface are not (Park et al, 2004). It remains to be studied whether the increased AMPA/NMDA ratio induced in the VTA DA neurons by in vivo administration of drugs of abuse is dependent on novel gene expression and/or protein synthesis, or rather due to other protein modifications such as receptor subunit phosphorylation/dephosphorylation or altered receptor recycling. BZs are not known to be potent inducers of gene expression. At a high acute dose of $30 \mathrm{mg} / \mathrm{kg}$, DZ produces brain-region-dependent reduction in the expression of genes such as c-Fos, CaMKII, and BDNF (Huopaniemi et al, 2004), believed to be essential for structural/functional modifications of synaptic organization. In attempt to clarify the molecular mechanisms of BZ-induced changes in synaptic glutamate transmission, the present study could be extended, eg by VTA DA neuronspecific gene expression profiling.

An important question is what this plasticity phenomenon means? Only the classical drugs of abuse are able to induce the enhancement of the excitatory transmission in VTA DA neurons, whereas two psychoactive, but nonaddictive drugs, fluoxetine and carbamazepine, fail to alter these synapses (Saal et al, 2003). In this study we show that DZ and ZOL, that also have abuse potential, are able to induce a long-lasting modulation of the excitatory transmission in these synapses. DZ treatment produced increased frequency of AMPA receptor mEPSCs in the VTA DA neurons. This modulation did not alter spontaneous locomotor or exploratory activity in mice (the present study), in agreement with the finding that overexpression of GluR1 subunit of the AMPA receptors by viral genetransfer in the VTA does not affect spontaneous locomotor activity in rats (Carlezon et al, 1997). Increased VTA AMPA receptors may, however, be facilitatory for morphineand stimulant-induced locomotor sensitization (Carlezon and Nestler, 2002). It could also be hypothesized that the specific effect that drugs of abuse, including the BZs, have on the excitatory synapses of VTA DA neurons would play a part in the reinforcing properties of those drugs. The mesolimbic DA system operates in reward expectation and processing, reward-based learning, and reinforcement (Wise, 1996; Waelti et al, 2001). Drug-induced enhancement of synaptic strength at excitatory synapses on the DA cells could facilitate further drug-induced alterations in the mesolimbic DA system, which could lead to excessive wanting of the drugs and thus to addictive behaviors. So far, the activation of AMPA receptor function has been linked primarily to the withdrawal state from chronic BZ treatment (see 'Introduction'), representing a homeostatic neuroadaptation in the form of upregulation of excitatory mechanisms in response to increased inhibition, and we cannot exclude that our findings might simply reflect the AMPA receptor upregulation in response to strong sedation by a single dose of BZs. On the other hand and more interestingly, our results may also stress a direct addiction potential for BZ-site agonists in addition to mere negative reinforcing capacity, such as alleviation of drug-withdrawal symptoms. The role of glutamatergic mechanisms and glutamate/DA interactions in rewarding and positive reinforcing effects of BZs should thus be further explored.

\section{ACKNOWLEDGEMENTS}

This work was supported by grants from the Academy of Finland, the Finnish Foundation for Alcohol Studies and the Sigrid Jusélius Foundation. Eeva Harju is gratefully acknowledged for her expert secretarial help and language correction.

\section{DISCLOSURE/CONFLICT OF INTEREST}

The authors have no conflicts of interest.

\section{REFERENCES}

Allison C, Pratt JA (2006). Differential effects of two chronic diazepam treatment regimes on withdrawal anxiety and AMPA receptor characteristics. Neuropsychopharmacology 31: 602-619.

Arbilla S, Allen J, Wick A, Langer SZ (1986). High affinity $\left[{ }^{3} \mathrm{H}\right]$ zolpidem binding in the rat brain: an imidazopyridine with agonist properties at central benzodiazepine receptors. Eur J Pharmacol 130: 257-263.

Ashton $\mathrm{H}$ (2005). The diagnosis and management of benzodiazepine dependence. Curr Opin Psychiatry 18: 249-255.

Atack JR, Smith AJ, Emms F, McKernan RM (1999). Regional differences in the inhibition of mouse in vivo $\left[{ }^{3} \mathrm{H}\right]$ Ro $15-1788$ binding reflect selectivity for $\alpha 1$ vs $\alpha 2$ and $\alpha 3$ subunit-containing $\mathrm{GABA}_{\mathrm{A}}$ receptors. Neuropsychopharmacology 20: 255-262.

Benavides J, Peny B, Dubois A, Perrault G, Morel E, Zivkovic B et al (1988). In vivo interaction of zolpidem with central benzodiazepine (BZD) binding sites (as labeled by $\left[{ }^{3} \mathrm{H}\right] \mathrm{Ro}$ 15-1788) in the mouse brain. Preferential affinity of zolpidem for the $\omega_{1}\left(\mathrm{BZD}_{1}\right)$ subtype. J Pharmacol Exp Ther 245: 1033-1041. 
Bonci A, Malenka RC (1999). Properties and plasticity of excitatory synapses on dopaminergic and GABAergic cells in the ventral tegmental area. J Neurosci 19: 3723-3730.

Cameron DL, Wessendorf MW, Williams JT (1997). A subset of ventral tegmental area neurons is inhibited by dopamine, 5-hydroxytryptamine and opioids. Neuroscience 77: 155-166.

Carlezon Jr WA, Nestler EJ (2002). Elevated levels of GluR1 in the midbrain: a trigger for sensitization to drugs of abuse? Trends Neurosci 25: 610-615.

Carlezon Jr WA, Boundy VA, Haile CN, Lane SB, Kalb RG, Neve RL et al (1997). Sensitization to morphine induced by viral-mediated gene transfer. Science 277: 812-814.

Coutinho CB, Cheripko JA, Carbone JJ (1969). Relationship between the duration of anticonvulsant activity of chlordiazepoxide and systemic levels of the parent compound and its major metabolites in mice. Biochem Pharmacol 18: 303-316.

Crestani F, Martin JR, Möhler H, Rudolph U (2000). Mechanism of action of the hypnotic zolpidem in vivo. Br J Pharmacol 131: 1251-1254.

Darcourt G, Pringuey D, Salliere D, Lavoisy J (1999). The safety and tolerability of zolpidem - an update. J Psychopharmacol 13: 81-93.

Di Chiara G, Imperato A (1988). Drugs abused by humans preferentially increase synaptic dopamine concentrations in the mesolimbic system of freely moving rats. Proc Natl Acad Sci USA 85: 5274-5278.

Dobrunz LE, Stevens CF (1997). Heterogeneity of release probability, facilitation, and depletion at central synapses. Neuron 18: 995-1008.

Ducic I, Puia G, Vicini S, Costa E (1993). Triazolam is more efficacious than diazepam in a broad spectrum of recombinant $\mathrm{GABA}_{\mathrm{A}}$ receptors. Eur J Pharmacol 244: 29-35.

Faleiro LJ, Jones S, Kauer JA (2004). Rapid synaptic plasticity of glutamatergic synapses on dopamine neurons in the ventral tegmental area in response to acute amphetamine injection. Neuropsychopharmacology 29: 2115-2125.

Faure-Halley C, Graham D, Arbilla S, Langer SZ (1993). Expression and properties of recombinant $\alpha 1 \beta 2 \gamma 2$ and $\alpha 5 \beta 2 \gamma 2$ forms of the rat GABA ${ }_{\mathrm{A}}$ receptor. Eur J Pharmacol 246: 283-287.

Finlay JM, Damsma G, Fibiger HC (1992). Benzodiazepine-induced decreases in extracellular concentrations of dopamine in the nucleus accumbens after acute and repeated administration. Psychopharmacology (Berl) 106: 202-208.

Fitzgerald LW, Ortiz J, Hamedani AG, Nestler EJ (1996). Drugs of abuse and stress increase the expression of GluR1 and NMDAR1 glutamate receptor subunits in the rat ventral tegmental area: common adaptations among cross-sensitizing agents. J Neurosci 16: $274-282$

Frey HH, Löscher W (1982). Anticonvulsant potency of unmetabolized diazepam. Pharmacology 25: 154-159.

Gobbi M, Barone D, Mennini T, Garattini S (1987). Diazepam and desmethyldiazepam differ in their affinities and efficacies at 'central' and 'peripheral' benzodiazepine receptors. J Pharm Pharmacol 39: 388-391.

Greenblatt DJ, Sethy VH (1990). Benzodiazepine concentrations in brain directly reflect receptor occupancy: studies of diazepam, lorazepam, and oxazepam. Psychopharmacology (Berl) 102: 373-378.

Griffiths RR, Johnson MW (2005). Relative abuse liability of hypnotic drugs: a conceptual framework and algorithm for differentiating among compounds. J Clin Psychiatry 66(Suppl 9): $31-41$.

Griffiths RR, Weerts EM (1997). Benzodiazepine self-administration in humans and laboratory animals - implications for problems of long-term use and abuse. Psychopharmacology (Berl) 134: 1-37.

Hajak G, Müller WE, Wittchen HU, Pittrow D, Kirch W (2003). Abuse and dependence potential for the non-benzodiazepine hypnotics zolpidem and zopiclone: a review of case reports and epidemiological data. Addiction 98: 1371-1378.

Harte M, O'Connor WT (2004). Evidence for a differential medial prefrontal dopamine D1 and D2 receptor regulation of local and ventral tegmental glutamate and GABA release: a dual probe microdialysis study in the awake rat. Brain Res 1017: 120-129.

Huang YY, Nguyen PV, Abel T, Kandel ER (1996). Long-lasting forms of synaptic potentiation in the mammalian hippocampus. Learn Mem 3: 74-85.

Hucker HB, Hutt JE, White SD, Arison BH, Zacchei AG (1983). Disposition and metabolism of (+)-5-methyl-10,11-dihydro-5Hdibenzo[a,d] cyclohepten-5,10-imine in rats, dogs, and monkeys. Drug Metab Dispos 11: 54-58.

Hunkeler W, Möhler H, Pieri L, Polc P, Bonetti EP, Cumin R et al (1981). Selective antagonists of benzodiazepines. Nature 290: 514-516.

Huopaniemi L, Keist R, Randolph A, Certa U, Rudolph U (2004). Diazepam-induced adaptive plasticity revealed by $\alpha 1 \mathrm{GABA}_{\mathrm{A}}$ receptor-specific expression profiling. $J$ Neurochem 88: 1059-1067.

Izzo E, Auta J, Impagnatiello F, Pesold C, Guidotti A, Costa E (2001). Glutamic acid decarboxylase and glutamate receptor changes during tolerance and dependence to benzodiazepines. Proc Natl Acad Sci USA 98: 3483-3488.

Jones S, Bonci A (2005). Synaptic plasticity and drug addiction. Curr Opin Pharmacol 5: 20-25.

Kauer JA (2004). Learning mechanisms in addiction: synaptic plasticity in the ventral tegmental area as a result of exposure to drugs of abuse. Annu Rev Physiol 66: 447-475.

Khan GM, Smolders I, Ebinger G, Michotte Y (2000). Flumazenil prevents diazepam-elicited anticonvulsant action and concomitant attenuation of glutamate overflow. Eur J Pharmacol 407: 139-144.

Klockowski PM, Levy G (1987). Simultaneous determination of diazepam and its active metabolites in rat serum, brain and cerebrospinal fluid by high-performance liquid chromatography. J Chromatogr 422: 334-339.

Koob GF (1992). Drugs of abuse: anatomy, pharmacology and function of reward pathways. Trends Pharmacol Sci 13: 177-184.

Korpi ER, Gründer G, Lüddens H (2002). Drug interactions at $\mathrm{GABA}_{\mathrm{A}}$ receptors. Prog Neurobiol 67: 113-159.

Lister RG, Greenblatt DJ, Abernethy DR, File SE (1984). Pharmacokinetic studies on Ro 15-1788, a benzodiazepine receptor ligand, in the brain of the rat. Brain Res 290: 183-186.

Liu QS, Pu L, Poo MM (2005). Repeated cocaine exposure in vivo facilitates LTP induction in midbrain dopamine neurons. Nature 437: 1027-1031.

Lüddens H, Korpi ER, Seeburg PH (1995). GABA $/$ /benzodiazepine receptor heterogeneity: neurophysiological implications. Neuropharmacology 34: 245-254.

Lüscher C, Nicoll RA, Malenka RC, Muller D (2000). Synaptic plasticity and dynamic modulation of the postsynaptic membrane. Nat Neurosci 3: 545-550.

Mandema JW, Gubbens-Stibbe JM, Danhof M (1991). Stability and pharmacokinetics of flumazenil in the rat. Psychopharmacology (Berl) 103: 384-387.

Margolis EB, Lock H, Hjelmstad GO, Fields HL (2006). The ventral tegmental area revisited: is there an electrophysiological marker for dopaminergic neurons? J Physiol 577: 907-924.

McClung CA, Nestler EJ (2008). Neuroplasticity mediated by altered gene expression. Neuropsychopharmacology 33: 3-17.

Neuhoff H, Neu A, Liss B, Roeper J (2002). I(h) channels contribute to the different functional properties of identified dopaminergic subpopulations in the midbrain. J Neurosci 22: 1290-1302.

O'Brien DP, White FJ (1987). Inhibition of non-dopamine cells in the ventral tegmental area by benzodiazepines: relationship to A10 dopamine cell activity. Eur J Pharmacol 142: 343-354. 
Okada H, Matsushita N, Kobayashi K (2004). Identification of $\mathrm{GABA}_{\mathrm{A}}$ receptor subunit variants in midbrain dopaminergic neurons. J Neurochem 89: 7-14.

Pan B, Hillard CJ, Liu QS (2008). Endocannabinoid signaling mediates cocaine-induced inhibitory synaptic plasticity in midbrain dopamine neurons. J Neurosci 28: 1385-1397.

Park M, Penick EC, Edwards JG, Kauer JA, Ehlers MD (2004). Recycling endosomes supply AMPA receptors for LTP. Science 305: $1972-1975$.

Park M, Salgado JM, Ostroff L, Helton TD, Robinson CG, Harris KM et al (2006). Plasticity-induced growth of dendritic spines by exocytic trafficking from recycling endosomes. Neuron 52: 817-830.

Petursson H (1994). The benzodiazepine withdrawal syndrome. Addiction 89: 1455-1459.

Pritchett DB, Sontheimer H, Shivers BD, Ymer S, Kettenmann H, Schofield PR et al (1989). Importance of a novel GABA $\mathrm{A}_{\mathrm{A}}$ receptor subunit for benzodiazepine pharmacology. Nature 338: 582-585.

Rowlett JK, Platt DM, Lelas S, Atack JR, Dawson GR (2005). Different $\mathrm{GABA}_{\mathrm{A}}$ receptor subtypes mediate the anxiolytic, abuse-related, and motor effects of benzodiazepine-like drugs in primates. Proc Natl Acad Sci USA 102: 915-920.

Saal D, Dong Y, Bonci A, Malenka RC (2003). Drugs of abuse and stress trigger a common synaptic adaptation in dopamine neurons. Neuron 37: 577-582.

Sarti F, Borgland SL, Kharazia VN, Bonci A (2007). Acute cocaine exposure alters spine density and long-term potentiation in the ventral tegmental area. Eur J Neurosci 26: 749-756.

Schmid G, Bonanno G, Raiteri L, Sarviharju M, Korpi ER, Raiteri M (1999). Enhanced benzodiazepine and ethanol actions on cerebellar $\mathrm{GABA}_{\mathrm{A}}$ receptors mediating glutamate release in an alcohol-sensitive rat line. Neuropharmacology 38: 1273-1279.

Schultz W (1998). Predictive reward signal of dopamine neurons. J Neurophysiol 80: 1-27.

Sieghart W (1995). Structure and pharmacology of $\gamma$-aminobutyric $\mathrm{acid}_{\mathrm{A}}$ receptor subtypes. Pharmacol Rev 47: 181-234.

Song J, Shen G, Greenfield Jr LJ, Tietz EI (2007). Benzodiazepine withdrawal-induced glutamatergic plasticity involves upregulation of GluR1-containing $\alpha$-amino-3-hydroxy-5-methylisoxazole-4-propionic acid receptors in hippocampal CA1 neurons. J Pharmacol Exp Ther 322: 569-581.
Spyraki C, Fibiger HC (1988). A role for the mesolimbic dopamine system in the reinforcing properties of diazepam. Psychopharmacology (Berl) 94: 133-137.

Stephens DN (1995). A glutamatergic hypothesis of drug dependence: extrapolations from benzodiazepine receptor ligands. Behav Pharmacol 6: 425-446.

Steppuhn KG, Turski L (1993). Diazepam dependence prevented by glutamate antagonists. Proc Natl Acad Sci USA 90: 6889-6893.

Sutton MA, Schuman EM (2006). Dendritic protein synthesis, synaptic plasticity, and memory. Cell 127: 49-58.

Thomas MJ, Beurrier C, Bonci A, Malenka RC (2001). Long-term depression in the nucleus accumbens: a neural correlate of behavioral sensitization to cocaine. Nat Neurosci 4: 1217-1223.

Ungless MA, Whistler JL, Malenka RC, Bonci A (2001). Single cocaine exposure in vivo induces long-term potentiation in dopamine neurons. Nature 411: 583-587.

Van Sickle BJ, Cox AS, Schak K, Greenfield Jr LJ, Tietz EI (2002). Chronic benzodiazepine administration alters hippocampal CA1 neuron excitability: NMDA receptor function and expression. Neuropharmacology 43: 595-606.

Waelti P, Dickinson A, Schultz W (2001). Dopamine responses comply with basic assumptions of formal learning theory. Nature 412: 43-48.

Wanat MJ, Hopf FW, Stuber GD, Phillips PE, Bonci A (2008). Corticotropin-releasing factor increases mouse ventral tegmental area dopamine neuron firing through a protein kinase C-dependent enhancement of $I_{\mathrm{h}}$. J Physiol 586: 2157-2170.

Wieland HA, Lüddens H (1994). Four amino acid exchanges convert a diazepam-insensitive, inverse agonist-preferring $\mathrm{GABA}_{\mathrm{A}}$ receptor into a diazepam-preferring $\mathrm{GABA}_{\mathrm{A}}$ receptor. J Med Chem 37: 4576-4580.

Wise RA (1996). Neurobiology of addiction. Curr Opin Neurobiol 6: $243-251$.

Xiang K, Tietz EI (2007). Benzodiazepine-induced hippocampal CA1 neuron $\alpha$-amino-3-hydroxy-5-methylisoxasole-4-propionic acid (AMPA) receptor plasticity linked to severity of withdrawal anxiety: differential role of voltage-gated calcium channels and $N$-methyl-D-aspartic acid receptors. Behav Pharmacol 18: 447-460. 